\title{
高齢者の援助行動経験と心理・社会的幸福・安寧感 との関連
}

\section{関西大学 妹尾香織 ${ }^{2} \cdot$ 高木修}

Helping behavior and psychosocial well-being in elderly people

Kaori Senoo (Graduate School of Social Psychology, Kansai University, Yamate-cho, Suita 564-0073) and Osamu Takagi (School of Sociology, Kansai University, Yamate-cho, Suita 564-0073)

This study examined relationship between everyday helping behaviors and psychosocial well-being in elderly people. Elderly people attending an institute for adult education $(n=471)$, age ranged from 57 to 82 , participated in the study. They completed questionnaires that assessed the following variables: everyday helping behaviors, psychological reactions to helping, and psychosocial well-being, defined as self-esteem, moral, and social integration. The data indicated that psychological reactions resulting from helping consisted of three components: "positive effects on the self and others," "negative effects on the self and others," and "positive effects on the self." The helper's psychological reactions to helping had a significant effect on self-esteem, moral, and social integration. There were gender differences in the effect of these variables. These results suggest that an affirmative helping experience in everyday life provides elderly people with a feeling of psychosocial well-being.

Key words: helping behavior, functions of helping behavior, psychosocial well-being, elderly.

他者に恩恵を与えることを意図して行う自発的な行 為は, 日常生活に抢いては, 親切, 人助け, 手伝い, 募金，ボランティア活動などのさまざまな形の援助行 動として現れている (Spacapan \& Oskamp, 1992；高 木，1998). 従来，援助は本来好ましい行動であり， ゆえに援助を提供する行為は社会的に高い価值を持つ とポジティブに評価され, 一方, 援助を要請する行為 は, 被援助者の独立心や能力感を脅かし, また，援助 を受容する行為は，被援助者に負債感を経験させると ネガティブに評価されてきた（Fisher，Nadlar，\& DePaulo, 1983 ; 西川, 1997).

今日，高齢者は，高齢社会に向けて取り組むべき社 会的課題の一つとされ, さまざまな分野において社会 的, 個人的な対処法が模索されている（田尾・西村・ 藤田，2003). 社会的支援の対象者として認知されて いる高齢者が，援助者の立場で積極的に他者を援助す るならば，その行動経験と高齢者の心理・社会的幸 福・安寧感とはどのように結びつくのだろうか.

近年の社会心理学の領域における援助行動研究で

本研究は, 財団法人ユニベール財団に提出した調查報告書 の調査データの一部を再解析し，加筆修正したものである。ま た, 本研究の一部は, 日本心理学会第 67 回大会 (2003) におい て発表した.
は, 従来援助の受け手として認知され，また処遇され てきた高齢者についても援助の担い手として位置づ け，彼らのボランティア意識と活動実態掞よび日常的 な援助行動が国内外で検討され，高齢者が援助者とし て行動し得る可能性やそのような行動が果たす心理的 機能に着目した研究がなされ始めている（Midlarsky \& Kahana, 1994 ; 妹尾・高木, 2002a, 2002b, 2003 ; 妹 尾・高木・箱井, 2000 ; 高木・妹尾，2002). 例えば, 高木・妹尾 (2002) は，高齢者が日頃近隣社会におい て身近な人々との間で取り交わす援助に着目して，援 助の授与や要請および受容の 3 側面の行動実態を援助 者と被援助者の両立場から同時に接近し，高齢者は， 援助者の立場での援助授与行動を最も行いやすいとい う結果を得ている。また，妹尾・高木（2003）は，居 住地域を中心にボランティア活動に従事する中高年層 を対象とし，ボランティア自身が平常時のボランティ ア活動経験で, 愛他的精神の高揚や人間関係の広がり や人生への意欲喚起といったポジティブな成果を得, それらの成果によってボランティア活動の継続が動機 づけられることを明らかにした。また，妹尾・高木 (2002a) は, 高齢者大学生を対象に, 援助行動経験が 被援助者の立場での被援助行動に及ぼす影響を検討 し，成功的援助行動の経験を持つ高齢者ほど，一層被 援助に対する態度が肯定的で, 動機づけが積極的であ るという関係を実証している。これらの先行研究は, 


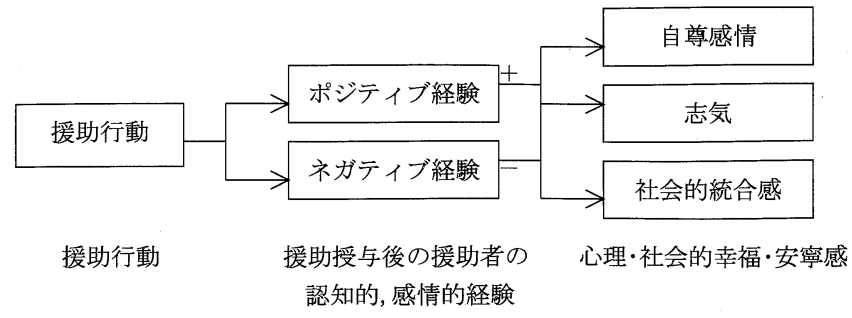

Figure 1. 本研究の枠組み.

高齢者におけるボランティア活動の有意義性や，高齢 者が現実問題に直面したときの適応的な援助要請と受 容のあり方に関して有用な情報を提供している.

ところで, 高齢者の心理的特徵について，藤田 （2000）は，様々な視点での研究が高齢者に対する否 定的ステレオタイプや否定的態度が存在し，高齢者を 取り巻く社会状況と高齢者自身の個人的欲求との間に 不協和が生じやすいことを指摘している。なお，その ような事態は，高齢者にとつて精神的にストレスフル な状況と考えられるが，援助授与が援助者自身の生活 ストレスに打ち勝つための有効な手段になるとの指摘 がある (Krause, Herzog, \& Baker, 1992; Midlarsky, 1991；高木，1998). 例えば，Krause et al. (1992) は，高齢者が援助を提供すれば，自己統制感が高ま り，抑うつ感が低減すると報告している。援助授与が 援助者自身の精神的健康に及ぼす効果について, 高木 （1998）によれば，一般に，援助者が有能で善良な存 在としてポジティブに評価されるのに対して，被援助 者が問題を自力で解決できない無能で急惰な存在とし てネガティブに評価される傾向がある。したがって， 生活ストレス状態にある人がストレスゆえに援助を受 容した場合にはネガティブに評洒され，精神的健康に 悪影響が及ぶが，逆に，ストレス事態に果敢に挑戦 し，他者に援助を授与した場合には積極的に行為する 能力を持ち続ける有能な存在としてポジティブに評価 され，精神的健康が高まると論じている，つまり，援 助を受容する立場にあるとして他者から処遇され，ま た，自己認識している高歯者が援助を行えば，主体的 で積極的な，有能な存在として自他がポジティブに評 価し，精神的健康が高まると考えられる。なお， Midlarsky (1991) は, 高齢者が援助を行えば, 次の ような心理・社会的幸福・安寧感が期待できると指摘 している.すなわち，(a)他者を助けることで，本来 的に援助を受ける対象であるにもかかわらず，困って いる人を積極的に助ける自分の姿を見て，低下してい る自尊心 は回復する (自尊心回復)。(b)人に役立っ たことで有意義な人生を送っているという充実感を味 わい, やる気が生まれる (志気高揚)。(c)援助を通じ て他者とのつながりを実感できる(社会的統合感)， である。
しかしながら，援助者の立場での援助授与は，必ず しも被援助者に喜ばれて成功するとは限らず，“おせ つかい”といつた言葉に代表されるように被援助者に 歓迎されないこともある.ところが，従来の援助行動 と心理・社会的幸福・安寧感に関する先行研究の多く は, 援助行動の指標として援助授与の有無や頻度, あ るいはフォーマル・インフォーマルといった援助場面 の効果が主として検討されており，援助授与の結果の 効果は十分に明らかでない.

そこで, 本研究では, 援助授与後の援助者の認知 的，感情的経験に着目し，援助者側の視座から，高齢 者の心理・社会的幸福・安寧感に寄与する，援助授与 の結果要因を検討する (Figure 1)。つまり，援助授 与経験が援助者自身にとってポジティブな場合は，援 助者の心理・社会的幸福・安寧感は高まるが, 反対 に，援助行動経験が援助者にとつてネガティブな場合 は, 援助者自身の心理・社会的幸福・安寧感は抑制さ れると予想される。そこで，援助授与が援助者自身や 被援助者にネガティブな結果を招いたとの認知やそれ に伴う情動経験も含めた援助授与後の援助者の認知 的，感情的経験の構造を解明し，これと，Midlarsky （1991）が高齢者が援助授与を通じて得ることが期待 できると指摘した，自尊感情，志気，社会的統合感が 実際に得られているかを検討する。

\section{方法}

\section{調査の対象者と手続き}

被調査者は，兵庫県内の高齢者大学を受講中の高齢 者 587 名である。2002 年 10 月末から 11 月初句にか けて, 高齢者大学の教職員の協力のもとで, 無記名自 記式の質問紙調查を実施した . 具体的には，高齢者 大学教職員を経由して調查票を配布し, 被調査者が自 宅等で回答した調査票を後日回収してもらい，回収さ れた調査票を第 1 著者の自宅に郵送してもらう形式で 実施した。なお，この調查は，高い回収率を確保する

3 調査票には, 後日実施を予定した聞き取り調查への協力を 呼びかけており，協力しても良いとする回答者には記名（氏名 と連絡先）を求めたが，自由意志からのものであり，そのこと による回答への影響はないものと考える. 
ために，図書券 500 円分の謝礼を準備し，調査票配布 時に，配布を担当した高齢者大学教職員が，被調查者 に手渡した。その結果，477名からの回答が得られた (回収率：81.3\%)。

\section{質問紙の構成 ${ }^{4}$}

フェイスシート 被調查者の属性として，性別，年 齢および現在の健康状態として生活自立度をたずね た。

援助授与行動の測定 西川（1997）の日常生活にお ける援助行動項目を松井・西川（2001）が高齢者向け に改訂した援助行動項目の中から 26 項目を選定した 妹尾・高木（2002b）の高齢者用援助行動尺度 ${ }^{5}$ の中 から因子負荷量の大きい, “健康を気遣っての電話”, “買い物の代行”, “講演会などの行事案内の通知”, “目的地への車での送迎”，“病院への同行”などの 13 項目を採用し，最近 3 か月間のそれらの授与経験の有 無をたずね，“経験あり”を 1 点，“経験無し”を 0 点 として, 単純加算したものを援助授与経験得点とした $(\alpha=.62)$. つまり, 援助授与経験得点が高いほど, 多 様な援助を行っていることを意味する。 また，現在， 普段の生活の中で, 誰に対する援助を行っているかに ついて，“子供や孫の世話”，“親の介護”，“配偶者の 世話”，“知人・友人への援助”，“地域社会への奉仕”, “各種ボランティア活動”, “偶然居合わせた見ず知ら ずの人への援助”，の回答選択肢の中から選択するこ とを求め, あわせて，その中でも最も力を入れて行っ ている援助授与行動を一つ選ぶように求めた。

援助授与後の認知的, 感情的経験の測定 妹尾 - 高 木 (2003) の援助後の援助者の心理的効果（援助成 果）に関する項目を参考にして，“相手が喜んでいる ことが伝わってきた”，“自分自身も得るものがあっ た”，“嬉しい気持ちになった”などの 11 項目で構成 した。なお，援助授与後の援助者の認知的，感情的経 験には，援助者にとってポジティブな心理的経験だけ でなく，援助の遂行がネガティブな結果をもたらした との認知やそれに伴う情動経験も含まれるという観点 から，質問項目には，“余計なことをしたと後悔し た”，“相手のプライドを傷つけてしまった”，“労力と 時間を無駄にしたと感じた”の 3 項目も含めた。そし て, 上述の現在最も力を入れている援助行動につい て，“あてはまる”（5点）から“あてはまらない”（1 点）までの 5 段階で評定してもらい, 得点が高いほど それぞれを強く感じているように配点した。

心理・社会的幸福・安寧感の測定 本研究では, 高

4 今回記載した以外にも調査項目は存在するが，今回の分析 には使用しなかったので省略した。

5 高齢者用援助行動尺度は, “精神的配慮”, “家事代行”, “社 会参加の機会提供”，“移動”，“役割”の5因子からなり，これ らの因子に高く負荷する項目を選択した.
齢者の心理・社会的幸福・安寧感の指標として, Midlarsky（1991）の知見に従って, 自尊感情, 志気, および社会的統合感を検討した。自尊感情は, Rosenberg（1965）が作成し，山本・松井・山成 （1982）が邦訳した 10 項目からなる “Self Esteem Scale”を用いた。そして，各項目について，“あては まる”（5点）から“あてはまらない”（1 点）までの 5 段階で評定してもらい, 得点が高いほど, 自尊感情 が高くなるように配点し, 各項目の評定值の合計点を 尺度得点とした $(\alpha=.78)$. 志気は, 古谷野・柴田・ 芳賀・須山（1990）の9項目からなる “Life Satisfaction Index K (LISK)”を用いた。 LISK は，高龄者の 主観的幸福感を測定する尺度として開発された Lawton（1975）の PGC モラールスケール (Philadelphia Geriatric Center Morale Scale) や既存の尺度に 基づいて開発された尺度で，“去年と同じょうに元気 である”，“年をとって前よりも役に立たなくなったと 思う（逆転項目）”などの項目で構成されている. そ して, 各項目について, “あてはまる”（5点）から “あてはまらない”（1点）までの 5 段階で評定しても らい，得点が高いほど，志気が高くなるように配点 し, 各項目の評定值の合計点を尺度得点とした $(\alpha=$ .72). 社会的統合感は, Liang, Dvorkin, Kahana, \& Mazian（1980）で用いられた項目を参考にして，“孤 独を感じる(逆転項目)”, “自分には大切な人がい る”，“普段人とやりとりしている”などの 6 項目で構 成した。そして，各項目について，“あてはまる”(5 点）から“あてはまらない”（1点）までの 5 段階で 評定してもらい, 得点が高いほど, 社会的統合感が高 くなるように配点し, 各項目の評定値の合計点を尺度 得点とした $(\alpha=.73)$.

\section{結 果}

\section{回答者の属性}

回収した 477 名の調查票のうち, 記入漏れが多かっ た 6 名を除く 471 名を分析対象（男性 246 名，女性 222 名, 性別不明 3 名, 平均年齢 67.8 歳 $(S D=$ 4.99), $\left.R=57-82, M_{0}=69\right)$ とした. 彼らの健康状態 については，“たいした病気や障害などもなく，普通 に生活している”が 349 名 (75.3\%), “何らかの病気 や障害などはあるが，日常生活はほぼ一大゙行光る し, 外出も一人でできる”が 112 名 (24.2\%), “何ら かの病気や障害などがあって, 日常生活や外出にある 程度の不都合がある”が 2 名 $(0.4 \%)$ で，回答者が 生活自立度の高い健康な高齢者であることが示され た.

また, 普段の生活の中で, 高齢者が現在最も力を入 れている援助は, 経験率の高い順に, “地域社会への 奉仕”(31.0\%), “各種ボランティア活動” (23.6\%), 
Table 1

援助授与後の援助者の認知的, 感情的経験の因子分析結果 $(N=381)$

\begin{tabular}{|c|c|c|c|c|c|}
\hline & 平均值 $(S D)$ & $\mathrm{F} 1$ & $\mathrm{~F} 2$ & $\mathrm{~F} 3$ & 共通性 \\
\hline 2. 相手の役に立てたと感じられた. & $4.14(0.81)$ & .746 & -.225 & .075 & .613 \\
\hline 1. 相手が喜んでいることが伝わってきた. & $4.17(0.85)$ & .645 & -.219 & .219 & .512 \\
\hline 6. 必要とされていることに充足感を感じた。 & $3.97(0.89)$ & .643 & -.122 & .264 & .498 \\
\hline 3. 誇りを感じた. & $3.23(1.13)$ & .490 & .103 & .318 & .352 \\
\hline 8. 相手の問題が解決した安堵感を得た. & $3.22(1.11)$ & .480 & .178 & .194 & .304 \\
\hline 9. 余計なことをしたと後悔した. & $1.76(0.96)$ & .095 & .808 & -.009 & .662 \\
\hline 11. 相手のプライドを傷つけてしまった. & $1.67(0.91)$ & .071 & .776 & .031 & .607 \\
\hline 10. 労力と時間を無駄にしたと感じた. & $1.66(0.89)$ & .022 & .719 & .100 & .528 \\
\hline 4. 自分自身も得るものがあった. & $4.03(0.93)$ & .206 & -.075 & .901 & .860 \\
\hline 7. 自分の勉強になった. & $3.97(0.96)$ & .300 & .025 & .632 & .490 \\
\hline 5. 嬉しい気持ちになった, & $3.99(0.89)$ & .486 & -.132 & .552 & .558 \\
\hline 因子寄与 & & 2.25 & 1.95 & 1.79 & \\
\hline 因子寄与率 $(\%)$ & & 20.41 & 17.73 & 16.26 & \\
\hline
\end{tabular}

注）回答は1=あてはまらない，3=どちらでもない，5=あてはまる。

“子供や孫の世話” (17.4\%), “知人・友人への援助” $(10.9 \%)$ ，“配偶者の世話” $(9.1 \%)$ ，“親の介護” (4.2\%), “偶然居合わせた見ず知らずの人への援助” (3.8\%) であることが示された。

\section{援助授与後の援助者の認知的, 感情的経験の構造解明}

援助授与後の援助者の認知的，感情的経験の構造を 明らかにするために，援助授与後の認知的，感情的経 験測定尺度 11 項目について, 主因子法で因子分析し, バリマックス回転を行った。主因子法を用いて得られ た各因子の固有值（初期解における固有値の減少傾向 は，第 I 因子から第 IV 因子まで，3.91，2.23，1.08， 0.70）を参考にして，3因子を抽出した。バリマック ス回転後の因子分析結果を Table 1 に示した。

第 1 因子には，“相手の役に立てたと感じられた”, “相手が喜んでいることが伝わってきた”などの自ら の援助授与が被援助者の役に立ったという実感に関す る項目と, “必要とされていることに充足感を感じ た”, “誇りを感じた”, “相手の問題が解決した安堵感 を得た”といった援助者自身の誇りや安堵，充足感と いったポジティブな感情経験に関する項目が，高い正 の負荷を示している。これらは，援助授与によって， 被援助者にも，援助した自分自身にも，ポジティブな 効果がもたらされたとの認識で共通しているため, “ポジティブ効果感” と命名した (5 項目， $\alpha=.74)$.

第 2 因子は，“余計なことをしたと後悔した”，“相 手のプライドを傷つけてしまった”，“労力と時間を無 駄にしたと感じた”が，高い正の負荷を示している. これらは，いずれも，自らの援助授与が，被援助者に も，自分自身にも，ネガティブな結果を招いたとの認
識で共通しているため，“ネガティブ効果感”と命名 した (3 項目， $\alpha=.81)$.

第 3 因子は，“自分自身も得るものがあった”，“自 分の勉強になった”，“嬉しい気持ちになった”が，高 い正の負荷を示している．これらは，援助授与による 援助者自身のポジティブな感情経験や好ましい認識を 示しており，“ポジティブ成果感” と命名した（3 項 目, $\alpha=.79)$.

\section{各変数の年齢差および性差}

回答者を平均年齢によって若年齢群 $(M=63.13$, $S D=2.76, \quad N=197)$ と高年齢群 $(M=71.34, \quad S D=$ 2.98, $N=258 ）$ 亿分類し，高・若年男女それぞれの， 援助授与経験，援助授与後の三つの認知的，感情的経 験, 自尊感情, 志気, 社会的統合感について, 性と年 齢を独立変数とした 2 要因の分散分析を行った (Table 2)。その結果，援助授与経験とポジティブ効 果感抢よびポジティブ成果感において，性別による主 効果が有意であり，男性よりも女性が日頃多様に援助 を行っており，また，自らの援助授与を，被援助者や 自分自身にポジティブな結果をもたらしたと男性より も強く感じていた。また，ポジティブ効果感におい て，年齢と性別の交互作用が見られた。そのため下位 検定を行ったところ，女性の場合，若年齢群よりも高 年齢群が，高年齢群の場合，男性よりも女性が，一層 ポジティブ効果感を得ていることが示された.

\section{高齢者の援助行動経験と心理・社会的幸福・安寧感の 関連性}

高齢者の援助行動経験と心理・社会的幸福・安寧感 
Table 2

尺度得点の平均と分散分析結果および変数間の相関関係

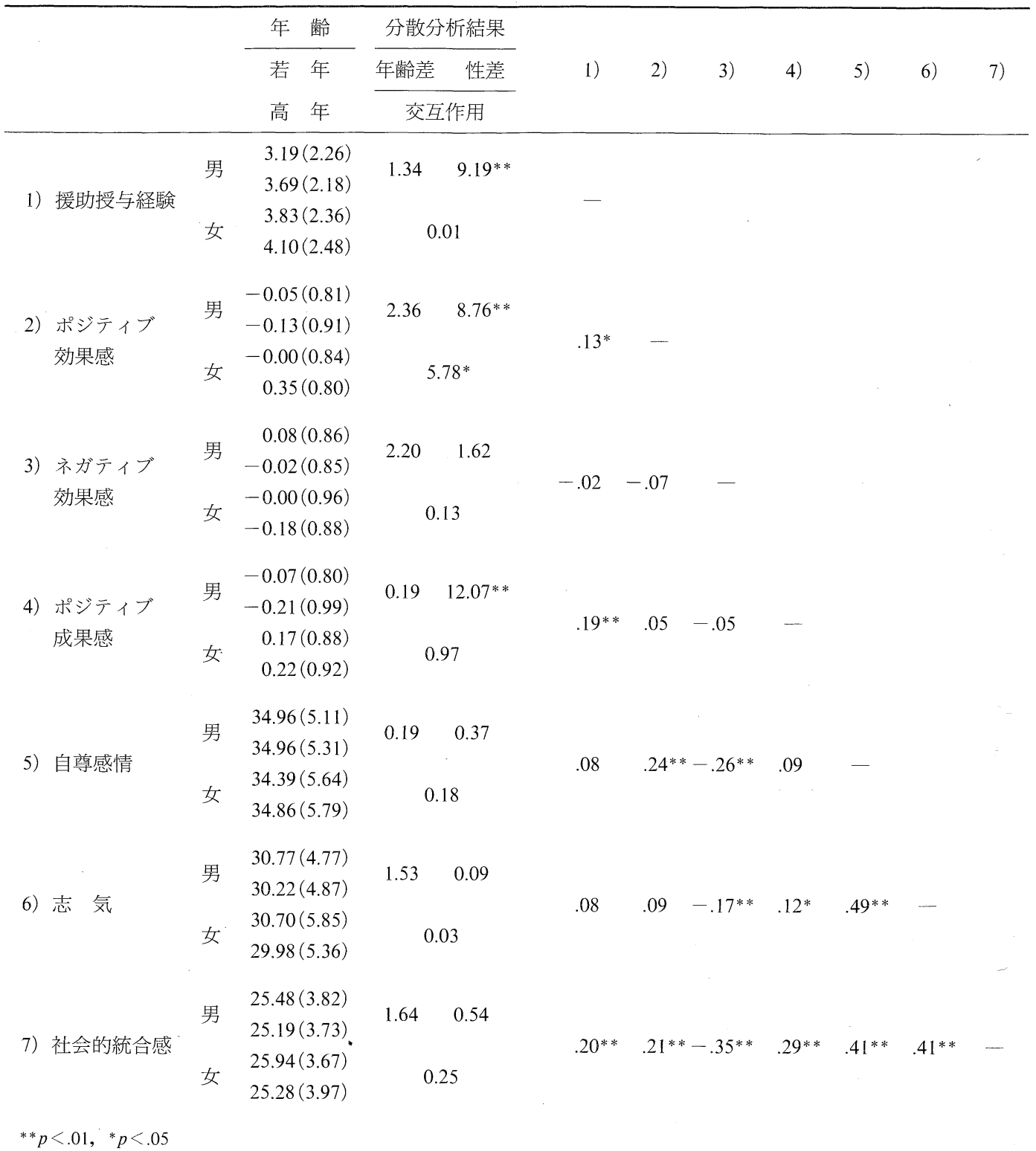

の関連性を検討するために，自尊感情，志気，社会的 統合感のそれぞれを目的変数とし, “ポジティブ効果 感”, “ネガティブ効果感”, “ポジティブ成果感”を説 明変数とする重回帰分析 ${ }^{6}$ 女, 男女別に行った (Table 3).

その結果, 男性の場合では, 自尊感情へは, “ポジ

${ }^{6}$ 重回帰分析には，Figure 1 のモデルに基づき，援助授与後 の援助者の認知的, 感情的経験に関する変数（ポジティブ効果 感，ネガティブ効果感，ポジティブ成果感）のみを説明変数と して投入した。
ティブ効果感”と“ネガティブ効果感”が，志気へ は, “ネガティブ効果感”と“ポジティブ成果感”が, 社会的統合感へは, “ポジティブ効果感”, “ネガティ ブ効果感”, “ポジティブ成果感”が有意な寄与を示 し, “ネガティブ効果感”はいずれも負の影響を示し た。

女性の場合では，自尊感情へは，“ポジティブ効果 感”と“ネガティブ効果感”が，社会的統合感へは, “ネガティブ効果感”, “ポジティブ成果感”が有意な 寄与を示し，“ネガティブ効果感” は男性と同様に， 
Table 3

自尊感情，志気，社会的統合感を規定する要因の重回㷌分析結果（男女別）

\begin{tabular}{|c|c|c|c|c|c|c|c|}
\hline \multirow{2}{*}{ 目的変数 } & \multirow{2}{*}{ 説明変数 } & \multicolumn{3}{|c|}{ 男 性 } & \multicolumn{3}{|c|}{ 女 性 } \\
\hline & & $\beta$ & $R^{2}$ & $F$ 值 & $\beta$ & $R^{2}$ & $F$ 值 \\
\hline 自尊感情 & ポジティブ効果感 & $.18^{*}$ & .09 & $6.13^{* *}$ & $.26^{* *}$ & .15 & $9.00^{* * *}$ \\
\hline （男性：N=189） & ネガティブ効果感 & $-.24^{* *}$ & & & $-.25^{* *}$ & & \\
\hline （女性：N=155） & ポジティブ成果感 & .06 & & & .06 & & \\
\hline 志 気 & ポジティブ効果感 & .04 & .05 & $3.38^{*}$ & .11 & .04 & $2.26^{+}$ \\
\hline （男性：N=195） & ネガティブ効果感 & $-.17 *$ & & & -.11 & & \\
\hline （女性：N=154） & ポジティブ成果感 & $.14^{*}$ & & & .11 & & \\
\hline 社会的統合感 & ポジティブ効果感 & $.22 * *$ & .23 & $19.92 * * *$ & .08 & .19 & $12.19^{* * *}$ \\
\hline （男性：N=200） & ネガティブ効果感 & $-.33^{* * *}$ & & & $-.30^{* * *}$ & & \\
\hline （女性：N=163） & ポジティブ成果感 & $.29^{* * *}$ & & & $.28^{* * *}$ & & \\
\hline
\end{tabular}

いずれも負の影響を示した。また，女性では，援助授 与経験と志気との関連はなかった。

\section{考 察}

本研究は，高齢者の援助授与行動に焦点をあて，援 助行動経験と心理・社会的幸福・安寧感との関連につ いて検討した。その結果，一部の結果を除いて，援助 者の立場で他者を援助し，その援助からポジティブな 感情や認識を抱いた経験が，高齢者の心理・社会的幸 福・安寧感と結びつく関係が明らかとなった。つま り，援助授与行動が必ずしも援助者の心理・社会的幸 福・安寧感を高めるのではなく, 授与した援助の結果 によることが示唆された。

まず，援助授与経験が寄与する心理・社会的幸福・ 安寧感は，男女で異なることが示された。男性では， 成功的な援助授与経験は, 自尊感情, 志気, 社会的統 合感のいずれも促進するが，女性では，援助授与経験 と志気との関連は認められなかった。また，性差は， 日頃の援助授与経験や援助授与後の認知的, 感情的経 験に扔いても確認された。男性よりも女性の方が，日 常的にさまざまな援助に多様に携わっていること，さ らに，女性が男性よりも，自らの援助授与を一層ポジ ティブに感じていることが明らかとなった。 また, 援 助授与後の認知的, 感情的経験によって, 自尊感情, 志気，社会的統合感へ及ぶ効果が異なることが示唆さ れた. 今回検討した援助授与後の援助者の認知的, 感 情的経験は，因子分析の結果，ポジティブかネガティ ブかだけでなく，援助の効果が誰に及ぶかに基づいて 3 因子が抽出された。ポジティブな経験に関しては, “ポジティブ効果感”，“ポジティブ成果感”の 2 因子 が抽出されたのに対して, ネガティブな経験として は，“ネガティブ効果感”の 1 因子であった。これは,
ネガティブな反応に関する項目が少なかったことも一 因と考えられる，この点については，今後の研究にお いてネガティブ反応の項目を増やすなどして検討する ことが必要と考光る。

高齢者の援助授与経験が心理・社会的幸福・安寧感 に及ぼす影響の中でも，社会的統合感への影響の強い ことが示された。高木・妹尾（2002）によれば，高齢 者にとって援助とは，援助者あるいは被援助者の立場 での身近な人との好意のやりとりを目的とした行動で ある。つまり，他者に対して自らの好意を表出し，そ の経験が自分自身にも他者にも効果的であれば，身近 な他者とのつながりや社会との関わり感が一層実感さ れると考光られる。

本研究は，普段の生活で高齢者が援助者の立場で他 者を助ける機会を持ち，その経験が成功的な場合は， 心理・社会的幸福・安寧感が促進されるが，反対に， 援助授与が被援助者や援助者自身に望ましくない結果 をもたらした場合は，彼らの心理・社会的幸福・安寧 感は抑制されることを明らかにした。しかしながら， ネガティブ効果感の各項目の平均值は低く, 高齢者が 日頃援助授与を通じてほとんど後悔や気まずさを感じ ていないことも示唆された。

藤田（2000） は高齢者が社会に適応するには，加齢 によって生ずる内的変化と外的変化を上手く処理する 必要があると指摘しているが，この過程において，援 助者の立場での援助授与行動は，高齢者の個人的欲求 を満たす行動として機能すると考えられる。したがっ て，今回の結果は，Midlarsky（1991）が指摘する “適応行動としての援助” (Helping as Coping) の一 事例を示したと考える。しかしながら，今回検討した 要因の分析に抢ける決定係数や標準回帰係数の数值は 十分とは言えず，Midlarsky（1991）や中谷（1997） 
および藤田（2000）が指摘するように，高齢者の心 理・社会的幸福・安寧感は多様な要因によって規定さ れることが示唆された。，その規定構造を今後検討する 必要があろう。また, 援助授与行動と心理・社会的幸 福・安寧感の因果関係を特定するためには, 縦断的な 手法を取り入れるなどの方法論上の工夫が必要と考え る。

\section{引用文献}

Fisher, J. D., Nadler, A., \& DePaulo, B. M. 1983 New directions in helping. Vol. 1. Recipient reactions to aid. New York: Academic Press.

藤田綾子 2000 高齢者と適応 ナカニシヤ出版

(Fujita, A.)

古谷野 亘・柴田 博・芳賀 博 - 須山靖男 1990 生活満足度尺度の構造一因子構造の不変性— 老年社会科学，12，102-116.

(Koyano, W., Shibata, H., Haga, H., \& Suyama, Y. 1990 Structure of life satisfaction index: Invariability of factorial structure. Japanese Journal of Gerontology, 12, 102-116.)

Krause, N., Herzog, A. R., \& Baker, E. 1992 Providing support to others and well-being in later life. Journal of Gerontology, 47, 300-311.

Lawton, M. P. 1975 The philadelphia geriatric center morale scale: A revision. Journal of Gerontology, 39, 85-89.

Liang, J., Dvorkin, L., Kahana, E., \& Mazian, F. 1980 Social integration and morale: A re-examination. Journal of Gerontology, 35, 746-757.

松井 豊・西川正之 2001 IV 近隣における高齢者 への援助人間・社会関係問題研究班(編) 人間 社会関係のダイナミクス——クロからマクロまで の多角的分析一一関西大学政治・経済研究所 Pp. 125-164.

(Matsui, Y., \& Nishikawa, M.)

Midlarsky, E. 1991 Helping as coping. In M. S. Clark (Ed.), Prosocial behavior. Newbury Park, CA: Sage. Pp. 238-264.

Midlarsky, E., \& Kahana, E. 1994 Altruism in later life sage library of social research 196. Thousand Oaks, CA: Sage.

中谷陽明 1997 高齢者の主観的幸福感と社会参加 下仲順子(編) 現代心理学シリーズ 14 老年心理 学 培風館 Pp. 140-149.

(Nakatani, Y.)

西川正之 1997 主婦の日常生活における援助行動の 研究 社会心理学研究，13，13-22.

(Nishikawa, M. 1997 A study of helping behavior among housewives in everyday life. Japanese Journal of Social Psychology, 13, 13-22.)
Rosenberg, M. 1965 Society and the adolescent self image. Princeton, NJ: Princeton University Press.

妹尾香織・高木 修 2002a 援助者に及ぼす援助行 動経験の効果 (4) 一一援助者, 被援助者からのアプ ローチによる高木（1997） モデルの検証——日本 社会心理学会第 43 回大会発表論文集，816-817.

(Senoo, K., \& Takagi, O.)

妹尾香織・高木 修 $2002 b$ 援助行動の構造とそれ らが及涩す心理的効果——高齢者の助け合いに関す る調查から (1) 一 日本心理学会第 66 回大会発表 論文集，108.

(Senoo, K., \& Takagi, O.)

妹尾香織・高木 修 2003 援助行動経験が援助者自 身に与える効果——地域で活動するボランティアに 見られる援助成果——社会心理学研究，18，106118 .

(Senoo, K., \& Takagi, O. 2003 The effect of helping behaviors on helper: A case study of volunteer work for local resident welfare. Japanese Journal of Social Psychology, 18, 106-118.)

妹尾香織・高木 修・箱井英寿 2000 シニア層のボ ランティア意識と実態 日本社会心理学会第 41 回 大会発表論文集，380-381.

(Senoo, K., Takagi, O., \& Hakoi, H.)

Spacapan, S., \& Oskamp, S. (Eds.) 1992 Helping and being helped: Naturalistic studies. Newbury Park, CA: Sage.

高木 修 1998 人を助ける心一一援助行動の社会心 理学——セレクション社会心理学 7 サイエン 久社

(Takagi, O.)

高木 修・妹尾香織 2002 高齢者による援助行動の 実態とその効用に関する研究 (1) ——近隣社会にお ける援助授受の実態と性別, 年齢, ボランティア活 動経験による差異——関西大学社会学部紀要,

34, 143-183.

(Takagi, O., \& Senoo, K. 2002 Helping behavior and its function in the elderly(1): Local helping behavior and the effects of the sex, age, and volunteer experience. Bulletin of the Faculty of Sociology, Kansai Univercity, 34, 143-183.)

田尾雅夫・西村周三・藤田綾子(編) 2003 超高齢社 会と向き合う 名古屋大学出版会

(Tao, M., Nishimura, S., \& Fujita, A.)

山本真理子・松井 豊・山成由紀子 1982 認知され た自己の諸側面の構造 教育心理学研究，30，6468.

(Yamamoto, M., Matsui, Y., \& Yamanari, Y. 1982 The structure of perceived aspects of self. Japanese Journal of Educational Psychology, 30, 64-68.)

- 2003.8.15 受稿, 2004. 5.22 受理—— 